\title{
THE POTENTIALS AND LIMITATIONS OF TAX DISPUTE PREVENTION AND ALTERNATIVE RESOLUTION MECHANISMS
}

Prof. dr. sc. Polonca Kovač*

\author{
UDK: 336.22 \\ https://doi.org/10.30925/zpfsr.39.4.3 \\ Ur.: 3. rujna 2018. \\ Pr.: 25. listopada 2018. \\ Izvorni znanstveni rad
}

\begin{abstract}
Summary
This paper deals with prevention and alternative dispute resolution (ADR) in tax matters, particularly in the light of the specific nature of administrative relations, which also include tax procedures. Given the involvement of stakeholders, ADR benefits both the taxpayers and the tax authority, enabling greater legal certainty and speedier finalisation of procedures. Yet, ADR also poses an open threat to the public interest and equality as international and constitutional administrative principles, and must therefore be limited in tax procedures. This also derives from the legal acts of the EU and the Council of Europe. In addition to theoretical frameworks and types of dispute prevention and resolution mechanisms studied by means of scientific literature review, legal sources analysis and comparative insights, the paper presents the Slovenian regulation and practice of the Financial Administration (FURS) over the past years. The aim of this research is to examine the de iure and de facto situation at the national level. The analysis shows that, in tax matters, ADR is noticeably more intensive at the international level than within national tax systems. On the other hand, individual countries prefer to establish regulatory mechanisms for prevention, which should result in even more desired avoidance of disputes. It can be concluded that efficient tax procedures require an integrated approach, including both dispute prevention and ADR, in order to ensure the principles of tax justice and systemic inclusion of all stakeholders in its governance.
\end{abstract}

Keywords: tax procedures; public interest; equality; dispute prevention; alternative dispute resolution (ADR); international trends; Slovenia.

* Polonca Kovač, Ph.D., Full Professor, University of Ljubljana, Faculty of Administration, Slovenia; polonca.kovac@fu.uni-lj.si.

This paper is written under support of the Croatian Science Foundation project no. 9366 "Legal Aspects of Corporate Acquisitions and Knowledge Driven Companies' Restructuring" and University of Rijeka project no. 13.08.1.2.01 "Protection of Beneficiary on the Croatian and European Financial Services Market". 


\section{INTRODUCTION}

Tax procedures constitute the formal legal framework for the assessment, calculation, payment, supervision and recovery of tax liabilities. In such context, tax relations are almost without exception considered a part of administrative relations. They express the relation between a super-, sub- or national authority and individual natural and legal persons, i.e. taxpayers, as defined by the regulator at a specific level of authority. This means that in tax procedures, it is necessary to take into account both the general principles of the administrative procedure ${ }^{1}$ and the specifics of tax relations.

Tax matters fall under commercial operations, which mainly aim at profit based on foreseeable relations and a rapid response of the players both within the countries and globally. However, more than other administrative matters, tax matters present a tendency for procedural efficiency. This means that it is already the regulator who creates the conditions for a safer and more responsive legal environment and develop new legal institutions, such as special taxpayers' statuses, advance rulings, or price agreements. Moreover, considerable attention is paid to the active role of participants in procedures, namely to the proactivity of the tax authority in implementing tax regulations and the participation of the taxpayers. ${ }^{2}$

Yet, one should not forget that the supreme principle in any administrative relation is lawfulness, which needs to be pursued when protecting the public interest. ${ }^{3}$ This also implies an absolute respect for substantive truth and several restrictions on the disposition of the subject matter of the procedure since, generally, public law relations are not dispositive. In tax matters, the public interest is the lawful repayment of liabilities in order to finance public needs. Namely, according to Article 3 of the Slovenian Tax Procedure Act (hereinafter: ZDavP-2), ${ }^{4}$ taxes are collected as revenues of the public budgets that do not represent payment for services rendered or goods supplied and are paid exclusively on the basis of taxation law or self-governing local

1 See Galetta, D.-U. et al., The General Principles of EU Administrative Procedural Law, Brussels, EP, 2015, Jerovšek, T., Kovač, P., Upravni postopek in upravni spor, Ljubljana, Faculty of Administration, 2017, pp. 17ff.

2 See, for instance, Perrou, K., Taxpayer Participation in Tax Treaty Dispute Resolution, Amsterdam, IBFD, 2014, pp. 227ff. Silvani, C., Dispute Resolution Procedures in International Tax Matters, IFA, 2014, pp. 39, 70, Edwards, H.T., ADR: Panacea or Anathema?, Harvard Law Review, vol. 99, 3/1986, pp. 668-684, Rogić Lugarić, T., Porezna tijela i porezni obveznici: od policajca i lopova do suradnika, in: Koprić, I. et al., Građani, javna uprava i lokalna samouprava: povjerenje, suradnja, potpora, Zagreb, Institut za javnu upravu, 2017.

3 Cf. Balthasar, A., ADR in Administrative Law, a major step forward to enhance citizens' satisfaction or rather a Trojan horse for the rule of law?, TAIEX, 2015, Dragos, D.C., Neamtu, B., ADR in European Administrative Law, Berlin, Heidelberg, Dordrecht, London, Springer, 2014, p. 209, Kovač, P., Izzivi alternativnega reševanja sporov v upravnih razmerjih v Sloveniji in širše, Ljubljana, ZZR PFL, vol. 76, 2017, p. 71. Cf. Galetta, D.-U., op. cit., p. 16., Jerovšek, T. et al., ZDavP-2 s komentarjem, Maribor, Ljubljana, Davčni izobraževalni inštitut, Davčno finančni raziskovalni inštitut, 2008, pp. 15ff.

4 Tax Procedure Act (ZDavP-2), Official Gazette of RS, No. 117/06. However, it is also necessary to take into account the subsidiary application of the General Administrative Procedure Act (GAPA), Official Gazette of RS, No. 80/99, see Art. 6 and 7 and related. 
community regulations issued on the basis of taxation law, whereby these funds are used for public needs as defined in the budget adoption procedures. Taxes may well be a coercive instrument of the state, but they are returned in the form of budgetary expenditure to all taxable entities, although in different ways. ${ }^{5}$ If approaches toward the taxpayers differ, ADR could jeopardise the public interest and equality before the law. Yet, this does not mean that in tax or other administrative procedures the administration should act bureaucratically, since good public governance requires a participatory and efficient public administration which assists the parties in the exercise of their rights and obligations, as long as such does not affect the public benefit or third parties.

This paper aims to determine the factors and legal sources that promote alternative and consensual approaches in tax relations, as well as to define the limitations in order to prevent abuse. With a theoretical analysis, comparative insights and a detailed study of the practice of the Slovenian tax authority - the Financial Administration of the Republic of Slovenia (FURS) - it focuses on the following research questions: What does classifying tax matters under administrative relations mean for the introduction of ADR in tax procedures? In what sense do the specificities of tax relations require or justify alternative approaches? What are the main legal institutions in European and Slovenian tax law that allow ADR? Which mechanisms or forms of ADR are most relevant in taxation matters in the national and international settings? Based on the above, the current state of ADR in tax procedures and the relevant development trends are examined.

In general, and specifically for the empirical part of the paper devoted to the analysis of FURS practice, the following hypothesis is put forward: Owing to the protection of the public interest and the prevalence of the principle of lawfulness, ADR is rather conservatively introduced in tax matters in Central Europe and particularly in Slovenia. This suggests that, despite the inevitable concern for lawfulness and equality, there are still possibilities to introduce ADR both at the regulatory and practical levels. The hypothesis is tested by means of an analysis of the relevant scientific literature, a normative analysis of international and national regulations, selected case law, and a statistical survey based on the annual reports of the FURS in recent years and structured interviews with FURS representatives conducted in the spring of 2018.

The second chapter focuses on the basics and the dilemmas concerning ADR in administrative relations in general, taking into account the specificities of tax matters. Next is a brief dogmatic definition of the key ADR institutions in Europe, following the established distinction between: (i) prevention, which leads to the avoidance of dispute, and (ii) dispute resolution when such arises. To illustrate the practice analysed, the third chapter examines the case of Slovenia whose tax system is comparable, for example, to the Croatian. ${ }^{6}$ These two countries share the Central

5 Decision of the Constitutional Court, U-I-297/95, 28 October 1998.

6 Cf. Žunić Kovačević, N., "Europeizacija" hrvatskog poreznog postupovnog prava - o dosadašnjim ne/uspjesima kroz prizmu zadanih i imperativnih promjena, GAPZH, vol. 5, 1/2014, pp. 78-91. Cf. Rogić Lugarić, T., op. cit. 
European administrative tradition, a (post)socialist legacy, and a relatively high degree of formalism in administrative matters. At the same time, there is a noticeable influence of the European Union (EU) and of the activities of the Council of Europe (CoE) that encourage the Member States to reach convergent solutions in the regulations and their implementation. ${ }^{7}$ The paper ends with a summary of the results of the research and a look at future trends.

\section{ON ADR IN TAX PROCEDURES AS ADMINISTRATIVE RELATIONS}

\subsection{Tax procedures and ADR as part of administrative relations - sources, dilemmas and trends}

Tax procedures are predominantly defined as administrative procedures since they generally denote the relation between a tax collecting authority and individual taxpayers. ${ }^{8}$ In this context, taxes - such as income tax, VAT, customs duties or other public charges - imply a non-voluntary financial charge which, as a rule, is a nonassigned public budget revenue (Article 3 of the ZDavP-2). The fact that they are not assigned is particularly important because it ensures 'stricter' lawfulness in relation to the taxpayers than the one generally applied under the ZUP (GAPA $\left.{ }^{9}\right)$. This, in principle, also limits the disposition of the subject matter of the procedure in the sense of ADR, unless a special act explicitly envisages a particular form of discretion of the tax authority.

In certain cases, tax authorities also conduct other types of procedures. For example, along with administrative powers, tax authorities are often given the power to establish minor offences related to non-compliance with tax legislation. Under the influence of EU practices, quasi-regulatory procedures are developed, for example when issuing abstract legal acts for a future state of facts, such as generalised (anonymised) advance tax rulings or advance price agreements (APA). Nonetheless, most of the tax procedures relate to the assessment, control of accounts and recovery of individual tax liabilities. This classifies them under administrative procedures, which, in the Central European systems, are conducted ex iure imperio in individual and concrete administrative relations between individual parties and authorities. ${ }^{10}$

7 Already at the level of administrative principles, see Galetta, D.-U., op. cit., for more on the tax system cf. Lang, M. et al., Procedural Rules in Tax Law in the Context of EU and Domestic Law, Wolters Kluwer, 2010.

8 This applies, despite the specifics of national tax systems and different legal traditions, to most tax procedures. More in Dragos, D.C., Neamtu, B., op. cit., Radvan, M., Tax Law as an Independent Branch of Law in CEE Countries, Lex Localis, vol. 12, 4/2014, pp. 816, 822, 823, Jerovšek, T. et al., op. cit., 2008, Kovač, P., Selected Slovenian tax procedure acts' simplifications and their implementation, Podjetje in delo, vol. 38, 2/2012, p. 396.

9 Jerovšek T. et al., op. cit., 2008, see commentary to Article 4 of the ZDavP-2 on the principle of legality. Cf. Jerovšek, T. et al., ZUP s komentarjem, Ljubljana, IPA, Nebra, 2004, commentary to Article 6.

10 Jerovšek, T., Kovač, P., op. cit., pp. 12-13, cf. Radvan, M., op. cit., p. 822. 
Taking into account the constitutionally guaranteed equal protection of rights, this automatically implies a subsidiary application of ZUP, despite the usually wide range of special rules in sector-specific legislation. ${ }^{11}$ Listed below are some general characteristics of administrative procedures as well as some specificities relating to tax matters, providing a framework for the analysis of ADR in individual subgroups of administrative processes.

The objectives of administrative procedures are multifaceted, yet at the same time complementary. Any administrative procedure must be conducted in the function of ensuring an efficient implementation of substantive law (e.g. tax laws) while at the same time providing for the protection of (constitutional) rights, with due account of the prevailing protection of the public interest over the a priori subordinate party. These are the twin objectives of administrative procedures, which are indeed contrary to each other, but the procedure needs to satisfy both. If the second function is an expression of the rule of law and a classic legal category, the first one is key for good public governance also from a political and sociological point of view. In this context, especially in the European setting, a third function of administrative procedures comes to the fore, namely establishing dialogue between the authorities and the subordinate parties (taxpayers). ${ }^{12}$ The latter are not only the subjects of decision-making, but rather active participants in the procedure since it is they who need to accept and implement the decisions issued by the authorities.

Regarding ADR, the main questions are what a dispute is and when a dispute in administrative matters occurs. According to international case law, "a dispute is a disagreement on a point of law or a fact, a conflict of legal views or of interests between two persons." ${ }^{13}$ A dispute is not necessarily a hostile conflict - it can merely be a different view of the legal or factual elements of the case, usually solved by means of legal remedies. As regards the occurrence of a dispute, different interpretations are suggested, particularly for procedures initiated ex officio, namely that a dispute arises with the beginning of a first instance procedure or when an appeal or different legal remedy is filed, or a dispute is initiated before the court. According to the practice of the European courts, ${ }^{14}$ the majority view is that a dispute arises only when the

11 In numerous decisions, the Constitutional Court ruled that tax procedures (also tax execution, for example) were special administrative procedures and required the legislature to consider that special regulations can deviate from ZUP only if there are reasonable grounds to regulate differently than the general regulation (e.g. the non-suspensive appeal under Article 87 of ZDavP-2 is thus considered to be consistent with the Constitution, gl. Jerovšek, T. et al., op. cit., 2008, pp. 227ff). The same can be found in the case law of the CJEU, e.g. in case Pelati d.o.o. v. Slovenia, C-603/10, 18 October 2012.

12 Hofmann, H. C. H. et al., The ReNEUAL Model Rules, ReNEUAL, 2014, p. 4. On the significance of personal contacts and dialogue in tax procedures see van Hout, D., Is Mediation the Panacea to the Profusion of Tax Disputes?, World Tax Journal, 2018, p. 95, Fronda, A., ADR: Alleviating burdens all around, ITR, 2014, p. 26, Lowell, C.H., Governale, J.P., Choosing a Dispute Resolution Method: Is an APA Always the Best Alternative?, JIT, 1998.

13 Perrou, K., op. cit., 2014, p. 44. Cf. van Hout, D., op. cit., p. 63.

14 See ECtHR cases Janssen v. Germany, 23959/94, 20. 12 2001, Božić v. Croatia, 22457/02, 29 June 2006. Thus, as a rule, a dispute does not arise already at the first administrative instance nor only with a procedure before the court, and lasts until the realisation of the administrative 
party disagrees with the decision made by the authority, i.e. when an appeal (albeit administrative) is filed. This is important because it leads into a dogmatic separation between the prevention of disputes through legitimate mechanisms before a decision is issued and the resolution of disputes that have already arisen.

Disputes are solved by classic or 'ordinary' mechanisms (the main ones being remedies before the court) and by alternative/consensual/peaceful/amicable mechanisms, friendlier to the participants in the procedure if, of course, an agreement can be reached. ${ }^{15}$ ADR is in fact based on certain assumptions, such as admissible disposition of the subject of the relation and willingness of the participants to collaborate. The 'A' in ADR thus stands for alternative (everything-but-litigation), amicable, agreeable or appropriate ${ }^{16}$ dispute resolution. The dispute should thus be resolved not only in formal legal terms, but also de facto.

It can be said that ADR is a tool that follows the establishment of balance between protection of the public benefit and the rights of parties. Such balance means a fair process ${ }^{17}$ It is therefore not surprising that the Council of Europe recommended, as early as 2001, to introduce ADR also in administrative matters, although with some systemic limitations compared to civil relations from which ADR actually originated. Thus, it adopted the Recommendation Rec (2001)9 on alternatives to litigation between administrative authorities and private parties, together with the CEPEJ Guidelines for a better implementation of the existing Recommendation on alternatives to litigation between administrative authorities and private parties (CEPEJ (2007)15, 7 December 2007). Several approaches are suggested, such as (i) prevention (e.g. consultation), (ii) special non-judicial procedures, e.g. internal reviews, arbitration, negotiated settlement, mediation or conciliation, and (iii) alternative judicial procedures. Altogether, it is an alternative approach, either in the context of classic procedures, such as administrative or judicial procedures, or as a parallel or alternate route. Most often, ADR is a processual form or set of forms rather than a substantive law institution. It is in fact essential that outside the administrative, judicial, or other procedure, the mediator cannot adopt an enforceable decision. As a rule, neither of the parties to the dispute has the possibility to do so, unless ADR is specifically recognised before the otherwise competent administrative authority, a notary public, a court, etc. Therefore, regulators often seek combinations between traditional procedures and ADR.

In the EU, the shift to ADR was initially an academic project to draft the 'EU administrative procedure act' (A regulation for an open, efficient and independent EU administration). ${ }^{18}$ Specifically for tax matters, the Council Directive (EU) 2017/1852

relation, including a possible enforcement (Kovač, P., op. cit., 2017, p. 70).

15 Cf. Silvani, C., op. cit., p. 12.

16 Fronda, A., op. cit., p. 28, Silvani, M., op. cit., p. 13, van Hout, D., op. cit., p. 58.

17 Edwards, H.T., op. cit., p. 671.

18 See draft, adopted on 9 June 2016, <http://www.europarl.europa.eu/sides/getDoc.do?pubRef=-// $\mathrm{EP} / / \mathrm{TEXT}+\mathrm{TA}+\mathrm{P} 8-\mathrm{TA}-2016-0279+0+\mathrm{DOC}+\mathrm{XML}+\mathrm{V} 0 / / \mathrm{EN}>$. On limits of ADR see Hofmann, H.C.H. et al., op. cit., p. 154: "[...] the working group on this book refrained from drafting a 'law on settlements agreements'. The question whether and under which circumstances settlement agreements and mechanisms of alternative settlements of disputes are licit is assessed very differently in the Member States. This heterogeneity is based on the different views on the 
of 10 October 2017 on tax dispute resolution mechanisms in the $\mathrm{EU}^{19}$ was adopted. In tax disputes, alternative solutions are sought because of several factors. Considering the wish for economic stability through legal certainty and increasingly globalised business transactions resulting in a growing number of tax disputes, it is impossible to tackle the situation if regulators and tax authorities are not more flexible. Examples from different countries show that both tax authorities and the taxpayers avoiding taxes bypass the purpose of the tax procedure. ${ }^{20}$

The above Directive is an expression of the special features of tax matters where, more than usual in administrative relations, there is a need for a quick and realised subject matter. In addition, in the field of taxes, particularly when searching for gaps between national systems in the global economy, there are plenty cases of bypassing the laws, from legalising the commitments by means of tax havens and aggressive tax planning to more or less criminalised tax evasion. In order to stop this, the EU attempted to achieve a more consensual dispute resolution as a win-win approach. Of key importance in such regard is the need for legal certainty, typical of commercial operations. ${ }^{21}$ In this respect, the Directive also serves as a model for national regulations, although the $\mathrm{EU}$ is focusing on cross-border issues (e.g. avoiding double taxation). Another issue worth mentioning here is the procedural autonomy in the EU Member States. In principle, the EU leaves it to the Member States to regulate the procedural elements, e.g. the legal remedies or the time limits in administrative procedures, at the national level. ${ }^{22}$ However, one must bear in mind that in the EU, taxation - and, in particular, customs law ${ }^{23}$ - is fairly centralised, contrary to most other legal areas.

The Directive provides for some basic mechanisms, such as (i) complaint, (ii)

principle of legality of administration. In the end this question is a topic of substantive law, not of administrative procedure law. Hence, Book IV does not provide for rules on the question if a settlement agreement or alternative dispute resolution can be closed at all."

19 OJ L 265/1, 14 October 2017. The deadline for transposition into national legislation is 30 June 2019.

20 E.g. in relation to providing for taxpayers' rights see ECtHR cases OAO Neftyanaya Kompaniya Yukos v. Russia, 14902/04, 29 January 2009, Jussila v. Finland, 73053/01, 23 November 2006. Cf. Perrou, K., op. cit. 2014, p. 37, emphasising fair trial and effective remedy according to ECtHR case law. As regards the actions made by the taxpayers, here is a quote by the British politician Margaret Hodge in relation to off-shores: "We are not accusing you of being illegal; we are accusing you of being immoral."

21 Cf. Galetta, D.-U. et al., op. cit., pp. 2, 17, Perrou, K., The Ombudsman and Process of Resolution of International Tax Disputes - protecting the "Invisible Party" to the MAP, WTJ, 2018, p. 103, Kovač, P., Jovanović, T., Ensuring tax stability through advance rulings in (Slovene) practice, in: Radić, Ž. et al., The legal challenges of modern world, 2017, pp. 338-341.

22 See also CJEU case Pelati C-603/10 (and others not related to taxes), based on principles of equivalence and effectiveness. More on convergence in EU administrative procedural and tax law in Hofmann, H.C.H. et al., op. cit., Lang, M. et al., op. cit., Pistone, P. (ed.), Legal Remedies in European Tax Law, Amsterdam, IBFD, 2009.

23 Particularly as stipulated by Regulation (EU) No 952/2013 of the European Parliament and of the Council of 9 October 2013, laying down the Union Customs Code (OJ L 269), and delegated regulation of Commission, Nos. 2015/2446 and 2015/2447. Cf. Lang, M. et al., op. cit., pp. 49-70. 
mutual agreement procedure (MAP), and (iii) dispute resolution by the Advisory or ADR commissions. The Directive also incorporates several established mechanisms previously promoted by the OECD and, to a limited extent, by the EU, among which MAP and arbitration. ${ }^{24}$ For all such mechanisms, it also defines the limitations and tries to overcome their shortcomings. For example, ADR can, as a procedural presumption for the use of legal remedies, lead to prolonged procedures, which is why the Directive pays particular attention to procedural timeframe and deadlines. Prescribed time limits apply inter alia to the notification of the receipt of the taxpayer's complaint, the tax authorities' acceptance or rejection of the complaint, requests to arbitrate, set-up of arbitral or ADR body, notification of final decision. In addition, the scope of disputes is extended and the transparency of disputes outcome guaranteed.

Considering the general characteristics of administrative matters and the specific features of tax procedures, it is possible to identify the main strengths and weaknesses or threats of ADR in tax relations. According to various sources and experience, the main strengths of ADR in general and in tax matters are: simpler, more flexible and faster procedures, dispute resolution according to the principle of fairness and not merely following strict legal rules, amicable settlement, as well as greater acceptability of decisions by the parties. ${ }^{25}$ The latter seems particularly relevant for administrative relations since the acceptance of a decision (particularly if the decision is a forced one) reflects the respect for the rule of law. Forcible regulation of relations leads to the need for repression, such as - in administrative matters - enforcement, inspection measures, criminal prosecution, all less democratic and more expensive in the long run. Therefore, the procedure is regarded as a tool of democracy, of participative administration or good governance. ADR (and the classic instruments, such as the right to be heard), on the other hand, leads to long-term compliance with regulations and the taxpayers internalising the decisions. ${ }^{26}$ Moreover, it is necessary to emphasise increasing taxpayers ' autonomy and cooperative compliance, particularly relevant for the field of taxes, as well as acceptance of taxes despite the burden involved, while providing for procedural and distributive justice. ${ }^{27}$ In such context, it is crucial that dispute resolution starts as soon as possible or, better still, that dispute is prevented. The stage of dispute dictates the form of the solution, as indicated by Figure 1 below. ${ }^{28}$ Another key advantage of ADR is to prevent disputes before the courts, i.e. to reduce court workload, particularly in the light of an increasing scope of tax disputes. Yet again, this depends on the stage of the conflict. In terms of system efficiency and tax

24 More in Perrou, K., op. cit., 2014, Silvani, C., op. cit., pp. 16-76.

25 Similarly Rec(2001).9, ad 8., Hafer, R., Dispute Review Board and Other Standing Neutrals, CPR, 2010, p. 5.

26 Kovač, P., op. cit., 2017, p. 73.

27 Van Hout, D., op. cit., pp. 50, 69, Perrou, K., op. cit., 2018, p. 104, Fronda, A., op. cit., p. 27. On increasing compliance see also Šinkovec, D., Large business approach in Slovenia - granting a special status, 2018.

28 Source: Hafer, R., op. cit., p. 2. Cf. van Hout, op. cit., pp. 64, 91, 97, Fronda, A., op. cit., p. 26, Dragos, D. C., Neamtu, B., op. cit., pp. v, viii, 63, 109, 118. In detail on preventing administrative measures v. resolving judicial disputes also in Perrou, K., op. cit., 2014. Cf. CoE, $\operatorname{Rec}(2001) .9$, ad 4 and 5. 
justice, this ADR objective is only legitimate when it is one of the accompanying reasons and not the main reason for ADR.

\section{Dispute Resolution Stages and Steps}

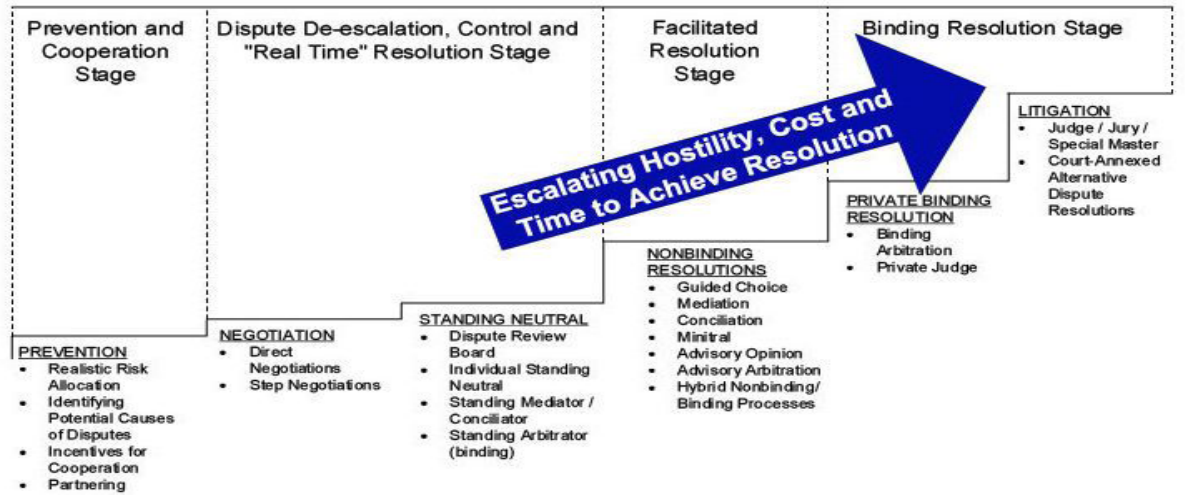

Figure 1: Dispute Prevention and Resolution Stages and Steps

On the other hand, there are a number of reservations or threats concerning ADR in administrative or tax matters. The main limitations are respect for lawfulness (in the sense of the tax authority's commitment to the law adopted in parliament) and equality of taxpayers. ${ }^{29}$ In such context, the subject matter of substantive and procedural rules is the definition of the public interest, and the tax authority could jeopardise it if the boundaries of the regulation were considered (too) broadly. Also, from the point of view of separation of powers and the administration being bound to the legislative branch, it is questionable how much discretion can the legislature allow to the tax authority to still comply with the Constitution. This is not per se inadmissible, yet it is necessary to define the scope and the explicit purpose of discretion and legal (judicial) protection. ${ }^{30}$

Furthermore, although the taxpayer does not have equal standing as the authority in administrative relations where the latter acts as the guardian of the superior public interest, the taxpayer has the possibility of actual participation and even co-decision. In such regard, the tax authority - based on the (purpose of) sectorspecific legislation - should act honestly (v. abusively) and proactively provide for voluntary cooperation. Of course, the taxpayer should also accept ADR openly, without concealment. In addition, there is limited confidentiality, which in civil disputes is one of the key principles of ADR, as tax transparency is an indispensable element in ensuring equality of the parties. The dilemma also arises as to how much a mediator or arbitrator in administrative relations can act impartially if such role is played by the tax authority as the inevitable decision-maker. At the same time, the

29 More in Kovač, P., op. cit., 2017, pp. 74ff.

30 CoE, Rec(2001).9, ad 10.-12. Cf. Jerovšek, T. et al., op. cit., 2004, pp. 52-71. 
above opens the possibility for ADR in the administrative procedure, since the dispute exists at least potentially between the public and private interests. On the other hand, however, due to the primary protection of the public benefit, dispute resolution is not as free as in a predominantly dispositive legal relation. The same as in civil procedure also applies in an administrative dispute in the administrative procedure, since the parties - considering the adversarial nature of procedures - are equal before the court, even if action is brought against a public law entity or issuer of an administrative act. Yet, even here, the key principle is lawfulness. The administrative authority and the court may amend the decision only if the previous one was unlawful, and not in order to reconcile public and private interests. One of the main problems in tax matters is that agreements are legally binding, final (res judicata) and enforceable ${ }^{31}$ If the agreement is enforceable, it is indeed less 'amicable' - otherwise, the authority has no assurance that what has been agreed will also be realised, which is essential for the administrative relation and the protection of the public interest (i.e. the collected tax). It is also unclear what happens if agreements or related acts (e.g. tax rulings) are challenged before the court ${ }^{32}$ or in relation to the related limitation period of the tax liabilities.

Thus, ADR fails to achieve the objectives of administrative procedures unless it meets the statutory goals of a specific relation or the sector-specific public interest. Obstacles to the ADR in tax matters and ultimately all administrative relations include legal and sociological elements. The legal are: (i) lawfulness as the (tax) administration being bound to the regulation and, thus, the non-dispositiveness of administrative matters; and (ii) respect of equality of the parties (taxpayers and parties in non-tax procedures) before the law. The sociological include: (iii) protection of the public benefit as the ratio of an administrative relation, and often (iv) lack of proactive administrative culture and institutionalised and qualified ADR holders..$^{33}$ Nevertheless, ADR, within the given limits, can be a useful complementary system, which at the same time legitimises the ratio of the administrative matter, since without a context the procedure may well be formally legitimate, but it implies maladministration.

\subsection{Typical prevention and ADR mechanisms in tax disputes}

Based on preliminary data and the analysis of general scientific and tax literature and legal sources, below is a brief dogmatic definition of the key institutions for the prevention and resolution of tax disputes in the European setting. Despite individual specifics, a general systematic scheme can be set up to consider the issue from a comparative and critical point of view. In this respect, it is essential to distinguish between dispute prevention and dispute resolution. ${ }^{34}$ Some sources emphasise a progressive approach, depending on the stage of conflict, namely: (i) negotiation

31 Cf. Balthasar, A., op. cit., Silvani. C., op. cit., pp. 14, 28.

32 See de van Velde, E., Tax Rulings in the EU MS, Brussels, EP, 2015, pp. 7, 24, 46; cf. Kovač, P., Jovanović, T., op. cit., pp. 339ff.

33 Kovač, P., op. cit., 2017, p. 80.

34 Cf. Perrou, K., op. cit., 2018, p. 109, Hafer, R., op. cit., p. 2, Kovač, P., op. cit., 2017, pp. 86ff. 
when conflict is considered a problem; (ii) mediation when conflict becomes personal; (iii) adjudication or arbitration when conflict is mainly concentrated on winning. ${ }^{35}$ This can be further elaborated as follows:

(A) Prevention covers:

i. quasi-tax or even regulatory (although individual) procedures, determining the relation toward a taxpayer for a future state of facts; these include mutual agreement procedures (MAP) under international law and APA, advance rulings and special statuses of (large) companies in national systems;

ii. measures applied during first instance tax procedure, intended to prevent dissatisfaction and use legal remedies; they are, by rule, of procedural nature and include consultation, negotiation, conciliation and, especially, mediation, followed by an individual and concrete administrative decision by the tax authority.

(B) Dispute resolution, generally by means of a less formalised procedure, comprises:

iii. substituted decisions in procedures involving legal remedies, particularly after an appeal or a motion to renew the procedure has been filed;

iv. arbitration as parallel to administrative and judicial protection, normally used in the event of dilemmas on jurisdiction, more in international than in national disputes.

(C) In addition, there are specific forms of agreements in individual tax systems that apply both in the stage of prevention as well as after legal remedies have been filed. Typically, these are:

v. substantive law measures to ease the tax burden, such as write-offs, instalments and suspensions;

vi. possibility of voluntary disclosure, which, per se, is not disputable if the tax authority acts as appropriate after the disclosure or tax return has been filed; yet, a dispute can arise after supervision has been carried out and result in an additional tax assessment. ${ }^{36}$

vii. This group also features procedural mechanisms from the first instance procedure, particularly mediation in a second instance administrative procedure or administrative dispute.

Table 1 outlines the mechanisms described above.

35 Van Hout, D., op. cit., pp. 64ff.

36 Cf. Langenmayr, D., Voluntary Disclosure of Evaded Taxes - Increasing Revenues, or Increasing Incentives to Evade?, Journal of Public Economics, vol. 151, 2017, pp. 110-125. 


\begin{tabular}{|c|c|c|c|}
\hline $\begin{array}{l}\text { Prevention or } \\
\text { resolution/ } \\
\text { Prevailing legal } \\
\text { character }\end{array}$ & $\begin{array}{l}\text { Dispute prevention, } \\
\text { i.e. before first- } \\
\text { instance tax } \\
\text { administrative } \\
\text { decision is issued }\end{array}$ & $\begin{array}{l}\text { Prevention and/or } \\
\text { resolution }\end{array}$ & $\begin{array}{l}\text { Dispute } \\
\text { Resolution }\end{array}$ \\
\hline $\begin{array}{l}\text { Substantive and } \\
\text { procedural }\end{array}$ & 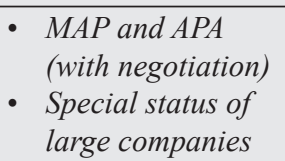 & $\begin{array}{l}\text { - Suspension and } \\
\text { instalments } \\
\text { - Voluntary disclosure } \\
\text { - Internal reviews }\end{array}$ & $\begin{array}{l}\text { Non-devolutive objection } \\
\text { or first-instance renewal }\end{array}$ \\
\hline Substantive & $\begin{array}{l}\text { Advance ruling, i.e. } \\
\text { tax, tariff and origin } \\
\text { customs information }\end{array}$ & & 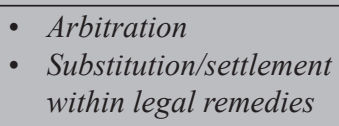 \\
\hline Procedural & $\begin{array}{l}\text { Negotiation, but } \\
\text { usually within, e.g. } \\
\text { APA or special status }\end{array}$ & $\begin{array}{l}\text { Mediation and similar, } \\
\text { particularly by } \\
\text { ombudsman }^{37}\end{array}$ & Mediation, etc. \\
\hline
\end{tabular}

Table 1: Types of Tax Dispute Prevention and Resolution Mechanisms (source: own)

Prevention mechanisms, in particular, aim at the issuing of general (implementing) acts or of abstract acts since the facts of taxation have not yet arisen. Both substantive aspects (e.g. subject to taxation, degree, reliefs) and procedural aspects may be involved. Advance price agreements (APA) are mainly a mechanism for bi/multilateral relations, directed against double taxation. ${ }^{38}$ Through APA, the tax authority and the taxpayer agree on transfer prices criteria, scope, methodology, prerequisites, and mandate. Similarly, the advance tax ruling is a letter of guarantee or pre-decision, i.e. a priori defining the tax assessment, insofar as the anticipated circumstances will arise. This ruling may also have a general character, provided it is anonymised and published. Despite being called an 'agreement', these are unilateral relations. ${ }^{39}$ However, there are some entry or eligibility conditions for the APA procedure to be initiated, which raises substantial doubts on the inequality of taxpayers..$^{40}$ Moreover, the CJEU can consider a special agreement as a form of state aid against EU law. ${ }^{41}$

37 More on the role of general or special (tax) ombudsman in Dragos, D.C., Neamtu, B., op. cit., pp. 565-588, Perrou, K., op. cit., 2018, van Hout, D., op. cit., p. 59.

38 For Croatia, see Žunić Kovačević, N., Prethodni sporazum o transfernim cijenama: stari izazovi ili nova era u poreznoj praksi, ZPFSR, vol. 39, 1/2018, pp. 457-476. Cf. Silvani, C., op. cit., pp. 86ff, Lowell, C.H., Governale, J.P., op. cit., pp. 8-11.

39 More in van de Velde, E., op. cit., pp. 33ff, Žunić Kovačević, N., Prethodna obvezujuća porezna mišljenja - novi institut hrvatskog poreznog postupka, ZPFSR, vol. 37, 1/2016, p. 275 (on unilaterality, therefore advance ruling is not an administrative agreement). Cf. Kovač, P., Jovanović, T., op. cit., p. 342.

40 Cf. Fronda, A., op. cit., p. 28. The problem escalated in November 2014 following the LuxLeaks scandal when the International Consortium of Investigative Journalists exposed several hundred secret tax rulings from Luxembourg. The LuxLeaks dossier allegedly documented how hundreds of multinational corporations were using the system in Luxembourg to lower their tax rates, in some cases to less than one per cent.

41 See, for instance, the tax scheme in the case Belgium \& Forum 187 ASBL v. Commission, 
As regards inequality, it is worth mentioning the relatively extensive case law stating that derogations from the general regulation are indisputable as long as there are reasonable grounds for distinction between different (groups of) beneficiaries. ${ }^{42}$

\section{EMPIRICAL STUDY ON ADR IN THE SLOVENIAN TAX PRACTICE}

\subsection{Briefly on the Slovenian tax regulation and the FURS}

Until 1996, tax procedures in Slovenia were not regulated separately by a special act. The related procedural issues were regulated by the ZUP as lex generalis. On 1 January 1997 and after Slovenia became a full EU member in 2004, the Tax Procedure Act came into force (versions of 1996, 2004 and 2006) and was amended several times. The currently applicable version (ZDavP-2) is very detailed and contains over 424 articles, despite provisional measures to reduce red tape. ${ }^{43}$ The Tax Procedure Act is subject to EU regulations (mostly related to customs) and directives, as well as further national substantive laws pertaining to approx. 30 taxes.

A characteristic of the Slovenian public administration and its social, political and legal systems is that they are closely related to the German and Austrian continental circle of the Rechtsstaat, which Slovenia made part of before 1930 and has been pursuing in its guidelines since its independence in 1991. Yet, having been part of the socialist Yugoslavia also left its mark. A combination of the rule of law, with constitutionally grounded separation of powers and public administration strictly bound by parliamentary law, and socialism-driven legacies still influences the functioning of the Slovenian public administration, understood primarily through government policies and formal public law. In terms of the economy, it is important to put forward that Slovenia has been part of Eurozone since 2007 and records $83 \%$ of EU average GDP per capita.

The ZDavP-2 introduces seven basic principles (legality, protection of public interest and taxpayers' rights, proportionality, privacy, etc.) and further legal grounds

C-182/03, C-217/03, 22 June 2006, even if only for the lack of transitional periods allowing the taxpayers to adapt to the necessary conditions. The court ruled as follows: "[...] annuls Commission Decision 2003/757/EC of 17 February 2003 on the aid scheme implemented by Belgium for coordination centres established in Belgium in so far as it does not lay down transitional measures for those coordination centres with an application for renewal of their authorisation pending on the date on which the contested decision was notified or with an authorisation which expired at the same time as or shortly after the notification of the decision."

42 See Jerovšek, T., Kovač, P., op. cit., pp. 56ff. For tax matters according to the Constitutional Court concerning the terms 'large companies', 'transfer prices', 'mothers', etc. (cf. Jerovšek, T. et al., op. cit., 2008).

43 More on the development of tax procedure law in Slovenia in Jerovšek, T. et al., op. cit., 2008, pp. $6 \mathrm{ff}$, Kovač, P, op. cit., 2012, pp. 397ff, Lang, M. et al., op. cit. pp. 591-614. Cf. with profiles in Lang, M. et al., op. cit., stating that for reasons of legal certainty, in Europe in general, the formalisation of tax relations is more a rule than an exception. Legal certainty is of crucial importance in such regard due to the constitutional requirement that taxes may only be imposed by law, as stipulated by Article 147 of the Slovenian Constitution. 
for tax collection. The proportionality in regulation, for instance, specifically requires the introduction of general tax reliefs and refrainment from conducting a procedure when the cost thereof would exceed the tax levied. Furthermore, it is important not to regulate a principle or a right merely on paper but also to regulate its efficient protection. ${ }^{44}$ Administrative procedures, tax procedures included, are, as a rule, two-instance procedures, providing for the right to appeal and further seek judicial protection before special administrative judiciary, constitutional and European courts. As in all administrative matters, the principle of truth and the official burden of proof lead the tax authority to protect the lawful collection of taxes.

The Financial Administration (FURS) was established in 2014 by merger of tax and customs administrations, today employing 2,695 officials. It operates through 15 regional, one special and one coordination general branch. There are approx. 2.8 mio tax procedures run annually, covering approx. 1.5 mio individual taxpayers and approx. 200,000 VAT and corporate income taxpayers (160,000 legal entities and individual entrepreneurs). Thus, FURS has been collecting around 15 billion EUR per year for the past few years, including social contributions and local taxes ${ }^{45}$ Basically, taxes are determined by tax accounts and deduction, while subsidiary assessment is carried out by individual administrative acts (decisions). Moreover, approx. 61,000 appeals are lodged every year, with slightly less than a half resolved by the Ministry of Finance as the appellate instance.

\subsection{Analysis of FURS data and position on tax disputes prevention and resolution}

In order to examine a possible gap between theory, regulations and practice, a survey was carried out in the spring of 2018 on the regulation of preventive and resolution mechanisms and its implementation in Slovenia. The findings for Slovenia are illustrative also for other countries with a similar legal and tax system, for example Croatia.

The research was based on the dogmatics presented in the previous chapter (2.2), with an analysis of the work of the Slovenian Financial Administration (FURS) in 2017 and before. In addition to scientific literature and comparisons of practices in other countries, the analysis covered, in particular, annual reports for 2016 and 2017 and, in some cases, data for several years in order to present the trends. Objective data were combined with the results of structured interviews with representatives of different sections/areas within FURS (tax assessment, supervision, enforcement, customs, etc.). FURS was very willing to cooperate. The interviews were held on 4 April 2018 on the basis of the recently published work report for 2017. It is worth mentioning that since 2014, FURS has comprised both the Tax Administration and the Customs Administration, and these two bodies have, at least at a first glance, a different perception of the same institutions (e.g. advance ruling or taxpayers' status),

44 Kovač, P., op. cit., 2012, p. 401, Silvani, M., op. cit., p. 6 (ubi ius ibi remedium).

45 Tax statistics is retrieved from public data, mainly annual reports, and available at the FURS website (http://www.fu.gov.si/). 
which makes the views of the representatives of different FURS services particularly interesting.

The analysis follows a fundamental division between (A) dispute prevention and (B) dispute resolution. Such distinction is not typical for FURS approaches and the official annual reports do not present this systematic approach. This makes the analysis to some extent more difficult, but also gives grounds to FURS - according to the opinion of the respondents in the April 2018 interview - to take a more comprehensive approach to the mechanisms in question. This would increase the level of proactivity and equality in relation to the taxpayers. Below is a detailed presentation of individual institutions, including when and how they were introduced and how much they apply in practice. The following are pointed out:

(A) Prevention: (A1) APA; (A2) advance rulings; and (A3) taxpayers' special status.

(B) Resolution: (B1) substitution in legal remedies; (B2) arbitration and mediation.

(C) Prevention and/or resolution, since the respective approaches can be seen as a prevention mechanism if applications meet the standards and are granted, otherwise a dispute might arise: (C1) suspensions and instalments of tax payment; (C2) voluntary disclosures.

(A1) APA was introduced into the Slovenian legal order under the influence of the EU with an amendment to the ZDavP-2 (only) in 2017 (Articles 14a to 14g). Detailed rules for the implementation of these provisions are laid down in the rules of the Ministry of Finance. The new regulation follows the OECD guidelines and the Dutch model. An APA is an ahead-of-time (!) agreement between the taxpayer and the tax authority on an appropriate methodology, critical assumptions and other appropriate criteria for determining the transfer pricing for a set of transactions over a fixed period of time. Depending on the role of the taxpayer, the agreements can be uni-, bi- or multilateral; the latter two are based on international double taxation treaties that allow such agreement. The ZDavP-2, however, limits the legitimacy of the beneficiaries depending on the categories in the Corporate Income Tax Act, namely to legal entities related by the nature of the matter operating with transfer prices and according to other prescribed limits. ${ }^{46}$ Regarding the preventive nature of the APA, the Act explicitly provides that, based on a written initiative by the taxpayer, the possibility of concluding an APA is discussed first and only after the taxpayer can submit a written application to the tax authority for the conclusion of the APA. Within three months, the tax authority informs the taxpayer whether the procedure will be carried out. The provisions are written in such a way as to emphasise the seriousness and continuous involvement of the taxpayer, but at the same time make the course of the procedure and the final conclusion of the agreement conditional on the consent of the authority. Such a wording indeed shows distrust toward the taxpayer. Along with a number of excluding clauses (see Articles $14 \mathrm{~h}$ to $14 \mathrm{f}$ ), this is probably also the reason why this institution does not truly come to life in practice. In fact, until April 2018, i.e.

46 Art. 16 of the Corporate Income Tax Act (ZDDPO-2, Official Gazette of GRS, No. 117/06 and amendments). 
over a year from the introduction of the APA, FURS received only two (!) applications. As regards APA, there is no established administrative practice in Slovenia, less so case law. It is completely unclear whether the taxpayer is entitled legal or judicial protection when the procedure is not initiated at all or the agreement is not concluded. According to FURS, this is not a separate tax procedure and an appeal would therefore be rejected as inadmissible. ${ }^{47}$ Likewise, the data on such procedures are not included in the annual reports. Considering international and constitutional principles on effective legal remedy and judicial review of the administration, it is impossible to agree with such position, more so in the light of the analogous nature and practice related to the longer-established advance rulings, which are also individual, although abstract acts that can be challenged in a judicial administrative dispute.

(A2) Advance rulings are regulated differently for tax and customs matters (i.e. binding tariff information - BTI and binding origin information - BOI), due to the significant differences in the legal nature thereof. Since 2016, customs rulings have been centrally regulated in the EU with the Union Customs Code as individual administrative acts (decisions, see Articles 33 to 37 of Regulation (EU) No 952/2013), thus allowing legal protection by means of an administrative appeal and before an administrative court. Disputes are rare, although in other countries they are also brought before the CJEU. ${ }^{48}$ On the other hand, the legal nature of tax rulings under Article 14 of the ZDavP-2 is not clear, while administrative practice and case law are inconsistent. ${ }^{49}$ Furthermore, the Act has several reserve clauses and the deadlines and costs (on average, EUR 4,770 per ruling) are defined rather broadly. According to FURS, tax advance rulings are indeed individual acts, but FURS considers them undisputable, which is systemically unacceptable in view of the Slovenian constitutional order. Moreover, there have been confusion and disputes in practice ever since 2006 when this institution was introduced, as there is no clear difference between the relevant acts that can be published anonymised as general acts and the explanations under Article 13 of the ZDavP-2. ${ }^{50}$ Given the above, it is not surprising

47 Article 14b of ZDavP-2 explicitly stipulates that an appeal for non-initiation of procedure is not possible. This is disputable at least in terms of the constitutional principles of lawfulness (discretion admissible only if explicitly determined by law, which must also define its purpose and limitations) and equality before the law. Also, there are no provisions on judicial protection in case of non-conclusion of the agreement.

48 See the Stryker case in the Netherlands, C-51/16, 26 April 2017, where the court classified the screws depending on the purpose of use among medical appliances rather than ironware, thus considerably lowering the customs duties for such products.

49 In details Kovač, P., Jovanović, T., op. cit. Cf. Žunić Kovačević, N., op. cit., 2016, van Velde, E., op. cit., 2014.

50 Cf. Jerovšek, T. et al., op. cit., pp. 24-44, Kovač, P., op. cit., 2012, pp. 400-403. The mandatory instructions for the interpretation of tax regulations under Article 13 were introduced in 2006 in order to avoid different interpretations of the same regulation among the 15 regional offices. The instruction was issued by the Minister of Finance or the Director-General of the tax service online. However, the institution, although its preventive purpose appears to be only added value, was not fairly implemented in practice by the tax authority. Thus, since 2017, it is no longer mandatory. On the efforts for stability see also Klun, M., Slabe-Erker, R., Business views of the quality of tax, environment and employment regulation and institutions: the Slovenian case, IRAS, vol. 75, 3/2009. 
that tax advance rulings in Slovenia are practically a dead letter in the law (see Table 2).

\begin{tabular}{|l|l|c|}
\hline \multicolumn{1}{|c|}{ Year } & \multicolumn{1}{|c|}{ Tax rulings (applications) } & Binding tariff information \\
\hline 2007 & $2(14)$ & N/A \\
\hline 2008 & $3(7)$ & N/A \\
\hline 2009 & $0(12)$ & N/A \\
\hline 2010 & $2(8)$ & 317 \\
\hline 2011 & $0(7)$ & 296 \\
\hline 2012 & $0(4)$ & 215 \\
\hline 2013 & $1(7)$ & 197 \\
\hline 2014 & $2(9)$ & 234 \\
\hline 2015 & $1(5)$ & 176 \\
\hline 2016 & $1(6)$ & 206 \\
\hline 2017 & $3(6)$ & 148 \\
\hline Total & $15(85)$ & 1,479 (year 2010-) \\
\hline
\end{tabular}

Table 2: No of advance rulings in Slovenia 2007 to 2017 (source: FURS)

(A3) The special taxpayers' status is another institution that is regulated and implemented differently in tax and customs matters, which gives rise to dilemmas about the proactive approach of tax authorities toward amicable relations. In the customs field, there is a single EU system provided under Articles 38 to 41 of the Regulation (EU) No 952/2013 on the authorised economic operator (AEO). The Regulation clearly states that the act granting such status is an individual administrative act with adequate legal protection, as is the case for all administrative decisions according to ZUP and before the courts. This is therefore a unilateral act of the customs authority, although the procedure involves some kind of agreement with the taxpayer. About 90 of these decisions are issued annually in Slovenia. In the tax field, this institution is based on Article 99 of the Financial Administration Act. ${ }^{51}$ The Act entered into force already in 2014, but due to the failure to adopt the implementing rules, this institution was ineffective until 2016. This was a loss also in the opinion of FURS, since a pilot project of horizontal monitoring with 18 large companies was taking place as early as 2010. The purpose of this project was to promote voluntary tax

51 ZFU, Official Gazette of RS, No. 25/14. Cf. Šinkovec, D., op. cit. The special status is to be acquired by taxpayers who: fulfil that they are liable for auditing according to the Companies Act (ZGD-1) and auditor's opinions without reservation for the last three years; they have implemented internal tax controls or they commit to implement them within two years after granting the special status; management submits a statement that they will inform the FURS about tax risks and enable access to all types of information; fulfil web (OECD) self-assessment questionnaire. The benefits include: transparently and jointly performing the programme, developing understanding and trust, increasing responsiveness and cooperative problemsolving; assigning special FURS contact persons, etc. The FURS naturally also expects higher compliance, albeit no evidence is gathered so far but it seems so, as stated by a FURS representative in the interview: "due to a process per se". Some companies voluntarily disclose this status as a reference, like the trade company Mercator or the Slovenian Post. 
compliance and reduce administrative burdens, and was recognised as exemplary in the international community. By April 2018, (only) eight such decisions were issued and two applications were filed for consideration. Considering that there are in Slovenia about 700 large companies and that, for example, an analogous status applies in the Netherlands for about 2,000 to 9,000 companies; the ratio 2\% (Slovenia) to $22 \%$ (the Netherlands) is significantly low. As in the case of APA, the statistics on these procedures are not included in the FURS annual reports, with the explanation that these are sui generis procedures involving tax secrecy, although by their legal nature these acts are defined as administrative decisions. This raises the already exposed dilemma of non-transparency and (possible) inequality of taxpayers. A more favourable tax status of the taxpayer than the one initially granted is always considered to be an interference with equality. But this, according to the established constitutional case law, seems undisputable, since the rules clearly state the criteria and objectives for differentiation and the system provides - both for the AEO and the tax statuses - for a regular verification of the conditions and for exculpatory provisions.

(B1) Regarding ADR, substitution in the application of legal remedies is of key importance in Slovenia for tax dispute resolution. ${ }^{52}$ The possibility of a substituted decision derives directly from Article 240 of ZUP. Article 87 of the ZDavP-2, on the other hand, stipulates that an appeal is non-suspensive, although it is possible to determine, on a case-by-case basis, that enforcement is suspended until the appeal is resolved. The substituted decision is issued by a first instance authority if it finds that the appellant is right, otherwise the appeal is referred to the appellate body. The FURS itself considers this institution as an explicit win-win approach for "trust building as well as an easier proceduralisation". This is confirmed by statistical data stating that for over a decade the appeal resolution rate has ranged between 60 and $70 \%$ already at the first instance (see Table 3). On the other hand, data show that the taxpayers are not given the possibility to be heard, which would prevent unjustified excessive taxation. This is due to such procedures being defined as shortened procedures as well as to insufficient records of (212!) municipalities about the characteristics of, for example, land for the assessment of real estate tax (here, together with the renewals, $90 \%$ positive decisions on legal remedy are issued). This phenomenon points to the urgency of a systematic approach by various parts of the public administration to prevent disputes, as they arise unnecessarily. Therefore, data on ADR success are relative.

\begin{tabular}{|c|c|c|}
\hline Year & All appeals & $\begin{array}{c}\text { Substituted decisions } \\
\text { No \% }\end{array}$ \\
\hline 2015 & 21,091 & 13,20763 \\
\hline 2016 & 23,241 & 14,67863 \\
\hline 2017 & 20,629 & 12,34260 \\
\hline
\end{tabular}

Table 3: No of appeals/complaints and substituted decisions in Slovenia 2015-2017 (source: FURS)

52 More in Dragos, D.C., Neamtu, B., op. cit., pp. 383-386. 
To get a comprehensive picture, it is necessary to point out, in addition to appeals, also the non-devolutive objections raised by the taxpayers regarding the personal income tax. About 40,000 objections are raised every year, which is only $3 \%$ of all cases, but about three quarters of them are justified. Also frequent are proposals to renew the procedure (about 11,000 in 2017). Interestingly, the number of regular and devolutive appeals decreases, while renewals - as an extraordinary non-devolutive legal remedy - increase, since the latter are more favourable for the taxpayers because of suspensiveness and longer time limits. Yet, even these cases could be significantly reduced, since Article 90 of ZDavP-2 provides a special legal remedy to annul or change the decision, if obviously wrong. Unfortunately, however, the Act limits the legitimacy to the taxpayers, even though FURS itself could eliminate such errors when the remedy is applied ex officio. This again shows that there are many possibilities of dispute prevention already at the regulatory level.

(B2) To continue, regarding mediation and arbitration as the most recognised ADR tools generally, there are practically no traces thereof in the Slovenian practice. The main reason that there is no sympathy for arbitration (e.g. according to the Portuguese model that has already been studied) is the lack of binding effect and enforceability, which could create more disputes than it would resolve, according to FURS. Moreover, FURS understands arbitration within administrative relations as a possible violation of equality, particularly in the absence of specific conditions for arbitrators and at least some formalisation of the procedure. ${ }^{53}$ FURS's perception of mediation is similar, since the respondents expressed doubts about bona fide of the taxpayers, as well as about the resulting lower workload of the court or speedier completion of judicial procedures ${ }^{54}$ Likewise, the Ombudsman in Slovenia, unlike in many other countries, is not taken sufficient advantage of. According to the reports, ${ }^{55}$ the Ombudsman deals with tax procedures and notes an increasingly excessive duration thereof over the years, particularly as regards the non-suspensiveness of appeal and the tax burden of the socially deprived persons or immigrants, but does not act as a systemic promotor of good administration or a mediator.

Contrary, the Slovenian tax system presents a rather high level of proactivity, on regulatory and implementation levels alike, as regards suspensions, instalments and voluntary disclosures (Slovenian: samoprijave) ${ }^{56}(\mathrm{C} 1)$ ZDavP-2 provides for various forms of suspension and payment by instalments, separately for natural and legal

53 On the contrary, it is worth mentioning that the Supreme Court in its decision Cpg 2/2014, 17 June 2014, ruled that also in administrative relations arbitration is generally admissible as parallel to judicial dispute, unless the arbitration agreement interferes with the sector-specific ius cogens.

54 As put forward by van Hout, D., op. cit., p. 97: “[...] mediation is no panacea for the profusion of tax disputes. Mediation can be very efficient to prevent disputes or deal with tax conflicts in particular cases, but it will not dramatically reduce the number of tax controversies." More on mediation in administrative law in general in Dragos, D.C., Neamtu, B., op. cit., pp. 589-605. On the comparative experiences of ombudsman, see Perrou, K., op. cit., 2018.

55 See Ombudsman's Annual Report for 2017. By 2017, the Ombudsman dealt with (only) 60 cases related to taxes (out of a total of 4,471); the justification rate was $12.6 \%$ (16\% for all).

56 Kovač, P., op. cit., 2012, pp. 408ff. Mostly, these institutions have been enacted in order to reduce red tape. 
persons (Articles 101 to 110), based on specific forms established by the 2004 version of the Act. Yet, the scope of individual mechanisms has been changing considerably over time (see Table 4 for a comparison between 2007 and 2017). FURS uses these options mainly at discretion or by means of legally required forms of insurance. Thereby, the Act is applied in practice, even though write-offs are limited as they can be considered state aid. The need to consider this a mechanism between prevention and resolution is shown by the fact that it is possible to ask for suspension after the issuance of the decision or in the already disputed enforcement procedure, whereby the interest rate proportionally increases as well. According to its representatives, FURS notes that the Act provides the same conditions for suspension and instalments, but rather grants applications for instalments than those for suspension. This is evident from the 2016 to 2017 trend, showing an increase of instalments and a heavy decline in approved suspensions. In the latter case, a large number of cases concerns 'quasisuspensions' whereby the taxpayers resolve successive debts. These accounted, for example, for about 16,000 out of 22,000 applications in 2017, with about 5,000 not paying any part of their tax liability.

\begin{tabular}{|l|c|c|c|c|c|}
\hline & 2007 & 2017 & 2017 v. 2007 & in EUR mio, 2017 & 2017 v. 2016 \\
\hline Instalments & 4,716 & 18,129 & $+384 \%$ & 52.61 & $+5 \%$ \\
\hline Suspensions & 819 & 158 & $-81 \%$ & 3.78 & $-45 \%$ \\
\hline Write-offs & 1,816 & 447 & $-75 \%$ & 0.25 & $-21 \%$ \\
\hline
\end{tabular}

Table 4: No of instalments, suspensions and write-off in Slovenia (source: FURS)

(C2) Voluntary disclosures are, again, imported into the Slovenian system from the Netherlands. They have been included in ZDavP-2 since 2007 as a win-win approach to increase tax compliance and thus compensate for the lack of FURS resources. This was inter alia recognised as good practice by the Fiscalis Risk Management Platform (2012). First, the number of voluntary disclosures was low, i.e. less than 500 in 2006. They increased to 8,562 in 2007 and have ranged around 20,000 per year ever since 2009. The total amount of tax collected based on voluntary disclosure rose from 2006 to 2017 by about $60 \%$, totalling approx. EUR 46 mio (Table 5). In 2017, voluntary disclosures generated approx. EUR 18 mio in 15,315 audits and approx. EUR 9.7 mio in 374 inspection controls. Inequality, which is a frequent criticism in such regard, and the resulting encouragement of a tax avoidance culture ${ }^{57}$ are prevented by gradually increasing penalty interest $(3,5,7 \%)$ depending on the time of voluntary disclosure, which under the 2017 amendment to ZDavP-2 can be filed even when inspection is already taking place. ${ }^{58}$ According to FURS, despite theoretical concerns, voluntary

57 Contrary in Langenmayr, D., op. cit., pp. 110, that introduction of voluntary disclosure increases tax evasion. However, the author states, based on US and German experience, that while such mechanisms increase the incentive to evade taxes, they nevertheless increase tax revenues net of administrative costs.

58 In one year only, this accounts for as much as EUR 3.8 mil of additional tax paid in 78 procedures, which obviously points to the success of this institution. The interests were considered also by 
disclosure is a well-functioning mechanism.

\begin{tabular}{|l|c|c|}
\hline Year & No. of voluntary disclosures & in EUR mio \\
\hline 2015 & 21,189 & 31.1 \\
\hline 2016 & 23,668 & 28.2 \\
\hline 2017 & 22,293 & 46.4 \\
\hline
\end{tabular}

Table 5: Voluntary disclosures in No. and EUR in Slovenia (source: FURS)

To summarise: the basic hypothesis that, in Slovenia and in the broader region, ADR is applied rather conservatively in tax matters due to the protection of the public interest, is hereby confirmed. One cannot say that there is no sensitivity for dispute prevention and resolution. Certain institutions, such as voluntary disclosure, are very vivid, but changes are introduced conservatively and partially. Thus, tax advance rulings and similar institutions seems dead in practice, while new mechanisms are introduced as a response to convergence or EU law, i.e. as indirect coercion rather than national activity. In particular, both the regulator and tax authority have reservations in implementing the 'true' ADR, but rather focus on preventive mechanisms. This means that in practice, they are often just a dead letter. ${ }^{59}$

\section{CONCLUSIONS}

Slovenia is one of the centralised and formalised countries that are rather strong in prevention on paper, but they are weak when it comes to a systematic approach and lack alternative resolution mechanisms. These countries cannot be regarded as forerunners in the field, since they act (too?) slowly and fragmentarily and often face implementation gaps, although new mechanisms are adopted on the basis of EU directives and convergence. For the time being, the prerequisite for agreement in administrative relations (tax relations included) is freedom to dispose of the subject of the procedure, which is, however, limited owing to the protection of the public interest and the equality of the taxpayers. The tax authorities seem to understand this as an $a$ priori obstacle to individual permissible and useful comparable mechanisms. In this sense, attention should be drawn to the importance of understanding the efficient and effective tax and administrative systems, and especially legal remedies. ${ }^{60}$ The often irreconcilable conflict between lawfulness and economy can only be overcome by balancing formality and flexibility.

the Constitutional Court in case U-I-356/02-14, 23 September 2004, and the Supreme Court on several occasions, e.g. X Ips 63/2017, 6. July 2017, arguing that in terms of equal tax base, voluntary disclosure does not differ from timely tax return.

59 This was established after several analyses (in addition to the research described in chapter 3.2), e.g. for advance rulings in Slovenia (Kovač, P., Jovanović, T., op. cit., p. 345) or similarly for advance rulings and APA in Croatia (Žunić Kovačević, N., op. cit., 2014, 2016, 2018).

60 Cf. Perrou, K., op. cit., 2014, pp. 208 and related, 2018, p. 129, van Hout, D., op. cit., pp. 90-95. 
It is therefore necessary to highlight the importance of a systematic approach to parallel prevention and resolution of both tax and administrative disputes. Comparative experience, e.g. from the Netherlands, Austria, Germany as well as the UK and the USA, which are transferable to our environment, show that the reservations toward the new approaches, arising from the protection of the public interest and equality, can be overcome through legally determined assumptions and limitations and by raising awareness about cooperation among the tax authorities and the taxpayers.

This opens up the possibility of introducing a broader or systematic ADR into the lex generalis (GAPA), since such regulations at the national and EU levels do not hinder ADR, but do not provide any motivational guidelines either, except for (the almost unused options of) settlement or classic remedies. Moreover, given the tax specifics, it is right (and fair) that tax regulations develop new forms of dispute prevention and resolution with due account of constitutionally permissible differences. These should be encouraged in order to develop a more systematic and widespread approach - possibly by including in the general law (ZUP) a guideline for further special regulations, which are to be arranged systematically, according to the stage of procedure, in the same law or in individual taxation acts, provided that they are applicable to individual taxes. A general regulation is useful for several reasons. First, it would lead to a systematic (re)definition of certain relations between public administration bodies and private stakeholders in a more cooperative way.

Second, administrative relations would be defined more efficiently if the law - the general ZUP for all administrative matters and ZDavP-2 for all tax procedures - provided the possibility of direct referral to a body or a subordinate discretionary clause to harmonise public interest with private ones within certain statutory limits. In doing so, the law should determine the conditions of the derogations, the limits of discretion and the purpose thereof, in order to provide teleologically-supported legal protection against abuses by both the authority and the parties. This is particularly true when such approaches bring more benefits than subsequent disputes, for example through binding information or voluntary disclosure in tax matters.

Despite the restrictions on administrative relations, dispute prevention and ADR in particular show what future development brings. Prevention and ADR in tax matters indeed make sense and have potential, especially in the context of the development of a modern, efficient and democratic administration - a fair and good administration. If the concept is thought-out and integrated into the public administration with systemic and sector-specific legislation and parallel measures for the development of administrative culture, it leads to a state governed by the rule of law with less repression. Since the public benefit is determined by (sector-specific) law, lowering the stringency of the enforcement thereof in terms of settlement between public and private interests might, without safeguards, be unlawful, both on the side of the parties and on the side of the administrative authority since they do not dispose of the public interest in the same way as the regulator. However, comparative experience shows that the public interest, the protection of which is the essence of administrative relations, is even more efficiently protected through ADR. Given the social environment and regional culture, it is not surprising that ADR flourishes primarily in cultures that pursue participation. In the Central European environment, regulatory solutions 
and the operational implementation of ADR will need to be consciously developed. Considering the development trends in the EU, this seems to be only a matter of time.

\section{LITERATURE}

1. Balthasar, Alexander, ADR in Administrative Law, a major step forward to enhance citizens' satisfaction or rather a Trojan horse for the rule of law?, Ankara, TAIEX seminar, 2015.

2. Constitutional Court of the Republic of Slovenia, <http://www.us-rs.si/odlocitve/>, 10. 8. 2018.

3. Council Directive (EU) 2017/1852 of 10 October 2017 on tax dispute resolution mechanisms in the European Union, Official Journal of the European Union L 265/1, 14 October 2017.

4. Council of Europe Rec (2001)9, Recommendation Rec (2001)9 of the Committee of Ministers to MS on alternatives to litigation between administrative authorities and private parties, $<$ https://rm.coe.int/16805e2b59>, 10. 8. 2018.

5. Court of Justice of the European Union, CJEU, $<\mathrm{https}: / /$ curia.europa.eu/jcms/jcms/j_6/ en/>, 10. 8. 2018.

6. Dragos, Dacian Cosmos, Neamtu, Bogdana (eds), Alternative Dispute Resolution in European Administrative Law, Berlin, Heidelberg, Dordrecht, London, Springer, 2014.

7. Edwards, Harry T., Alternative Dispute Resolution: Panacea or Anathema?, Harvard Law Review, vol. 99, 3/1986, pp. 668-684.

8. Fronda, Aaran, Alternative dispute resolution: Alleviating burdens all around, International Tax Review, September 2014, pp. 26-28, <www.intrenationaltaxreview.com>, 25. 8. 2018.

9. FURS, interviews with FURS representatives on ADR, Ljubljana, 4. 4. 2018.

10. FURS, Letno poročilo 2017, Ljubljana, 2018, <http://www.fu.gov.si/o_financni_upravi/>, 15. 8. 2018.

11. Galetta, Diana-Urania, Hofmann, Herwig C. H., Mir Puigpelat, Oriol, Ziller, Jacques, The General Principles of EU Administrative Procedural Law, Brussels, European Parliament, 2015, <http://www.europarl.europa.eu/RegData/etudes/IDAN/2015/519224/ IPOL_IDA(2015)519224_EN.pdf>, 10.8. 2018.

12. Hafer, Randy, Dispute Review Board and Other Standing Neutrals, International Institute for Conflict Prevention \& Resolution (CPR), 2010, <https://www.cpradr.org/ resource-center/toolkits/construction-briefing-dispute-resolution-boards-other/_res/ $\mathrm{id}=$ Attachments/index $=0$ /CPR-Dispute-Review-Boards-and-Other-Standing-NeutralsConstructiontitle.pdf>, 15. 8. 2018.

13. Hofmann, Herwig C. H., Schneider, Jens-Peter, Ziller, Jacques (eds), The ReNEUAL Model Rules, ReNEUAL, 2014, <www.reneual.eu/>, 15. 8. 2018.

14. van Hout, Diana, Is Mediation the Panacea to the Profusion of Tax Disputes?, World Tax Journal, February 2018, pp. 43-97.

15. Jerovšek, Tone, Kovač, Polonca, Upravni postopek in upravni spor, Ljubljana, Faculty of Administration of the University of Ljubljana, 2017.

16. Jerovšek, Tone, Simič, Ivan, Škof, Bojan (eds), Zakon o davčnem postopku s komentarjem, Maribor, Ljubljana, Tax Education Institute, Tax and Finance Research Institute, 2008.

17. Jerovšek, Tone, Trpin, Gorazd (eds), Zakon o splošnem upravnem postopku s komentarjem, Ljubljana, Institute for Public Administration, Faculty of Law of the University of Ljubljana, Nebra, 2004.

18. Klun, Maja, Slabe-Erker, Renata, Business views of the quality of tax, environment and employment regulation and institutions: the Slovenian case, International Review of Administrative Science, vol. 75, 3/2009, pp. 529-548. 
19. Kovač, Polonca, Izzivi alternativnega reševanja sporov v upravnih razmerjih v Sloveniji in širše, Ljubljana, Zbornik znanstvenih razprav Pravne fakultete v Ljubljani, vol. 76, 2017, pp. 69-97.

20. Kovač, Polonca, Selected Slovene tax procedure act's simplifications and theirs implementation, Podjetje in delo, vol. 38, 2/2012, pp. 395-416.

21. Kovač, Polonca, Jovanović, Tatjana, Ensuring tax stability through advance rulings in (Slovene) practice, in: Radić, Željko, Rončević, Ante, Yongqiang, Li (eds), The legal challenges of modern world, 22nd International Scientific Conference on Economic and Social Development, Split, 2017, pp. 337-347.

22. Lang, Michael, Pistone, Pasquale, Schuch, Josef, Staringer, Claus (eds), Procedural Rules in Tax Law in the Context of European Union and Domestic Law, Alphen aan den Rijn, Wolters Kluwer, 2010.

23. Langenmayr, Dominika, Voluntary Disclosure of Evaded Taxes - Increasing Revenues, or Increasing Incentives to Evade?, Journal of Public Economics, vol. 151, July 2017, pp. $110-125$.

24. Lowell, Cym H., Governale, Jack P., Choosing a Dispute Resolution Method: Is an APA Always the Best Alternative?, Journal of International Taxation, March 1998, 11pp.

25. Perrou, Katerina, Taxpayer Participation in Tax Treaty Dispute Resolution, Amsterdam, IBFD, 2014.

26. Perrou, Katerina, The Ombudsman and Process of Resolution of International Tax Disputes - protecting the "Invisible Party" to the MAP, World Tax Journal, February 2018, pp. 99-129.

27. Pistone, Pasquale (ed.), Legal Remedies in European Tax Law, Amsterdam, IBFD, 2009.

28. Radvan, Michal, Tax Law as an Independent Branch of Law in Central and Eastern European Countries, Lex Localis, vol. 12, 4/2014, pp. 813-827.

29. Rogić Lugarić, Tereza, Porezna tijela i porezni obveznici: od policajca i lopova do suradnika, in: Koprić, Ivan, Musa Anamarija, Giljević, Teo (eds), Građani, javna uprava i lokalna samouprava: povjerenje, suradnja, potpora, Zagreb, Institut za javnu upravu, 2017.

30. Silvani, Cesare, Dispute Resolution Procedures in International Tax Matters, IFA, 98pp, 2014.

31. Supreme Court of the Republic of Slovenia, <http://www.sodnapraksa.si/>, 10. 8. 2018.

32. Šinkovec, Darija, Large business approach in Slovenia - granting a special status, presentation, the Hague, March 2018, internal material.

33. Varuh človekovih pravic RS, Ombudsman, Letno poročilo za leto 2017, <http://www. varuh-rs.si/publikacije-gradiva-izjave/letna-porocila-priporocila-dz-odzivna-porocilavlade/>, 25. 8. 2018.

34. van de Velde, Elly, Tax Rulings in the EU MS, Brussels, European Parliament, 2015, <http://www.europarl.europa.eu/RegData/etudes/IDAN/2015/563447/IPOL IDA(2015)563447 EN.pdf>, 25. 8. 2018.

35. ZDavP-2, Zakon o davčnem postopku [Tax Procedure Act], Official Gazette of the Republic of Slovenia, no 117/06 and amendments.

36. ZUP, Zakon o splošnem upravnom postopku [General Administrative Procedure Act], Official Gazette of the Republic of Slovenia, no 80/99 and amendments.

37. Žunić Kovačević, Nataša, „Europeizacija” hrvatskog poreznog postupovnog prava - o dosadašnjim ne/uspjesima kroz prizmu zadanih i imperativnih promjena, Godišnjak Akademije pravnih znanosti Hrvatske, vol. 5, 1/2014, pp. 78-91.

38. Žunić Kovačević, Nataša, Prethodna obvezujuća porezna mišljenja - novi institut hrvatskog poreznog postupka, Zbornik Pravnog fakulteta Sveučilište u Rijeci, vol. 37, 1/2016, pp. 267-289.

39. Žunić Kovačević, Nataša, Prethodni sporazum o transfernim cijenama: stari izzazovi ili nova era u poreznoj praksi, Zbornik Pravnog fakulteta Sveučilište u Rijeci, vol. 39, 1/2018, pp. 457-476. 


\section{Polonca Kovač*}

Sažetak

\section{POTENCIJALI I GRANICE MEHANIZAMA PREVENCIJE I ALTERNATIVNOG RJEŠAVANJA POREZNIH SPOROVA}

Ovaj rad bavi se prevencijom i alternativnom rješavanjem sporova (ADR) u poreznim pitanjima, u kontekstu upravnih odnosa. ADR, na temelju sudjelovanja dionika, koristi i poreznim obveznicima i poreznom tijelu, jer donosi osobito veću pravnu sigurnost i brzu konačnu zatvaranje postupaka. Istovremeno ADR znači otvorenu prijetnju javnom interesu i jednakosti po međunarodnim upravnim $\mathrm{i}$ ustavnim načelima, zato mora biti ADR u poreznim postupcima ograničeno. Ovo također proizlazi iz akata EU i Vijeća Europe. Osim teorijskih okvira i vrsta ADR na bazi analize znanstvene literature, pravnih izvora i komparativnih uvida u ovom radu bavi se o regulatornom okviru u Sloveniji i praksi Financijske uprave Republike Slovenije (FURS) u posljednjih nekoliko godina. Cilj istraživanja je identifikacija de iure i de facto stanja na nacionalnoj razini. Analiza pokazuje, da je ADR u poreznim pitanjima znatno intenzivnija u međunarodnim odnosima nego unutar nacionalnih poreznih sustava. S druge strane, pojedine zemlje nastoje uspostaviti osobito regulatorne mehanizme za prevenciju, što bi dovelo do još poželjnijeg izbjegavanja sukoba. U zaključku, istaknuto je, da su za efektivne porezne postupke potrebne integrirane metode prevencije kao i ADR, uzimajući u obzir principe pravednog poreznog sustava i uključenosti svih dionika u njegovo upravljanje.

Ključne riječi: porezni postupci; javni interes; jednakost; prevencija sporova; (alternativno) rješavanje sporova; ADR; internacionalni trendovi; Slovenija.

* Dr. sc. Polonca Kovač, redovita profesorica, Sveučilište u Ljubljani, Fakultet za upravu, Slovenija; polonca.kovac@fu.uni-lj.si. 
Zussamenfassung

\section{POTENZIALE UND BESCHRÄNKUNGEN DER VORBEUGUNG DES STEUERSTREITS UND ALTERNATIVE STREITBEILEGUNGSMECHANISMEN}

Dieser Beitrag bespricht die Vorbeugung des Steuerstreits und alternative Streitbeilegungsmechanismen (ASB-Mechanismen), insbesondere angesichts des spezifischen Wesens der Verwaltungsverhältnisse, welche auch Steuerverfahren einschließen. Sowohl Steuerpflichtige als auch die Steuerverwaltung haben Nutzen von den ASB-Mechanismen, weil sie hohe Rechtssicherheit und schnellere Beendigung der Verfahren ermöglichen. Die ASB stellt aber ein Risiko für das Gemeinwohl und die Gleichheit dar, die völker- und verfassungsrechtlichen Grundsätze. Deshalb muss die ASB bei Steuerverfahren beschränkt werden. Diese Behauptung geht auch von den Rechtsakten der EU und des Europäischen Rates hervor. Dieser Beitrag untersucht die theoretischen Rechtsrahmen und die Arten der Vorbeugung und Beilegung des Streites durch die Analyse der wissenschaftlichen Literatur, der Rechtsquellen und der rechtsvergleichenden Einsichten. Zusätzlich werden im Beitrag die slowenische Regulierung dieses Bereichs und die Praxis der Finanzverwaltung (der sog. FURS) in den letzten Jahren dargestellt. Das Ziel des Beitrags ist es, die de iure und de facto Situation in nationalen Rechtsordnungen zu untersuchen. Die Analyse weist darauf hin, dass die ASB öfter auf internationaler als auf nationaler Ebene verwendet wird. Andererseits geben individuelle Länder der Bestimmung von Regulierungsmechanismen für die Vorbeugung den Vorzug, was zur gewünschten Streitvermeidung führen sollte. Es lässt sich schließen, dass man einen integrativen Ansatz zur Erreichung effizienter Steuerverfahren braucht, welcher sowohl die Vorbeugung des Streits und die ASB einschließt, um die Grundsätze der Steuergerechtigkeit und die systematische Einbeziehung aller Interessenvertreter zu gewährleisten.

Schlüsselwörter: Steuerverfahren; Gemeinwohl; Gleichheit; Streitvorbeugung; alternative Streitbeilegung; ASB; völkerrechtliche Trends; Slowenien. 
Riassunto

\section{IL POTENZIALE E LE LIMITAZIONI DEI MECCANISMI DI PREVENZIONE E DI RISOLUZIONE ALTERNATIVA DELLE LITI TRIBUTARIE}

Il presente lavoro si occupa della prevenzione e della risoluzione alternativa delle liti (ADR) nelle questioni tributarie, nel contesto dei rapporti amministrativi. L'ADR, in base alla partecipazione delle parti, serve anche ai contribuenti ed agli enti tributari, in quanto comporta una maggiore certezza del diritto ed una chiusura rapida e definitiva della lite. Al tempo stesso l'ADR rappresenta una minaccia aperta per l'interesse pubblico e per l'uguaglianza secondo i principi internazionali amministrativi e costituzionali. Pertanto, l'ADR nella materia tributaria incontra dei limiti. Ciò deriva altresì dagli atti dell'UE e del Consiglio d'Europa. Oltre che del quadro teorico e dei tipi di ADR in base all'analisi della letteratura scientifica, delle fonti giuridiche e della rassegna comparata, in questo lavoro ci si occupa anche del quadro regolatore in Slovenia e della prassi dell'amministrazione finanziaria della Repubblica di Slovenia (FURS) negli ultimi anni. Lo scopo della ricerca è quello di identificare de iure e de facto la situazione sul piano nazionale. L'analisi dimostra che l'ADR nelle questioni tributarie è assi più intensa nei rapporti internazionali che all'interno dei sistemi tributari nazionali. Dall'altra parte, i singoli paesi cercano di creare dei meccanismi regolatori di prevenzione, il che porterebbe ad un auspicato scongiuramento del conflitto. Nella conclusione è stato rilevato che per delle procedure tributarie efficienti siano necessari dei metodi di prevenzione integrati come anche l'ADR, tenendo conto dei principi di un sistema fiscale giusto e dell'inclusione di tutte le parti nella sua gestione.

Parole chiave: procedimenti tributari; interesse pubblico; uguaglianza; prevenzione delle liti; risoluzione (alternativa) delle liti; ADR; tendenze internazionali; Slovenia. 
